\title{
Household Willingness to Pay for Forest Ecological Restoration in Giant Panda Habitats: A Discrete Choice Experiment
}

\author{
Yijing Zhang, Huihui Wang and Wei Duan *
}

check for updates

Citation: Zhang, Y.; Wang, H.; Duan, W. Household Willingness to Pay for Forest Ecological Restoration in Giant Panda Habitats: A Discrete Choice Experiment. Forests 2021, 12, 1735. https://doi.org/10.3390/f12121735

Academic Editors: Yaoqi Zhang and Luis Diaz-Balteiro

Received: 10 October 2021

Accepted: 2 December 2021

Published: 9 December 2021

Publisher's Note: MDPI stays neutral with regard to jurisdictional claims in published maps and institutional affiliations.

Copyright: (c) 2021 by the authors. Licensee MDPI, Basel, Switzerland. This article is an open access article distributed under the terms and conditions of the Creative Commons Attribution (CC BY) license (https:/ / creativecommons.org/licenses/by/ $4.0 /)$.
College of Economics \& Management, South China Agricultural University, Guangzhou 510642, China; yijing-zhang@scau.edu.cn (Y.Z.); huihuizier@163.com (H.W.)

* Correspondence: duanwei@scau.edu.cn

Abstract: Rural households have played an increasingly significant role in the conservation and restoration process of natural habitats. This paper explores rural households' preference and willingness to pay for ecological restoration attributes in giant panda habitats using the discrete choice experiment (DCE). The DCE survey was conducted in and around giant panda habitats in Sichuan province with a sample size of 474 . Using the mixed logit model, the results indicate that rural households have positive attitudes towards the improvement of ecological restoration functions, including forest vegetation restoration, biodiversity conservation, and giant panda corridor construction, but have a negative attitude towards payment, showing that rural households are inclined to pay less to gain better restoration outcomes. Among the ecological restoration attributes, forest vegetation restoration (4.44 RMB) wins the highest payment value, indicating households' preferences and priorities of ecological restoration. In general, rural households' willingness to pay could reach 34.28 RMB for the best choice option designed in DCE. This study emphasizes the awareness of payment among rural households to improve ecological restoration functions in giant panda habitats and indicates the importance of household participation in long-term adaptation and implementation of ecological conservation plans.

Keywords: ecological restoration; discrete choice experiment; willingness to pay; giant panda habitats

\section{Introduction}

For an ecosystem that has been degraded, damaged, or destroyed, ecological restoration plays a vital role in halting and reversing degradation, maintaining ecosystem functions, and promoting biodiversity [1,2]. As an essential carrier of an ecosystem, habitats are a rich biodiversity base to protect wild animal and plant resources [3]. Strengthening the protection of natural habitats could increase vegetation cover, foster the integrity of the ecosystem, enhance biodiversity, and promote sustainability.

Participation and management of ecological restoration call for multi-stakeholders' efforts in the decision-making and implementation process. Both externally driven initiatives and self-organized local stakeholders are expected to be involved in an endeavor of ecological restoration [4]. As the most important externally driven authority, the government is a significant force to restore the ecosystem by implementing policy and ecological restoration projects. In China, policies include the "construction of Ecological Civilization" (fundamental tenets are to respect, protect and adapt to nature, low-carbon use, and sustainable development) and the "Protection and Restoration of Mountains, Water, Forest, Farmland and Grass" to promote the national level restoration goals [5,6]. Ecological restoration projects are more engineering feature projects such as environmental engineering and afforestation projects focusing on the regional ecological restorations $[7,8]$. Several papers have analyzed ecological restoration projects from beforehand designing to afterward evaluation $[9,10]$.

Since natural habitats and the surrounding communities form a close unity, rural households are the most important local stakeholders to engage in ecological restora- 
tions [11,12]. However, local stakeholder reactions could range from passive information receivers to fully collaborative participators [13]. Generally, rural households have rarely participated in ecological restoration and have impeded the coordinating development of the ecosystem due to their conflicts in natural resource use, infrastructure construction, and comparatively low environmental protection awareness [14-16]. Although short-term government subsidies could stimulate local stakeholder behaviors in ecological restoration, these actions could disappear when locals no longer benefit from the subsidies [17]. Thus, active and collaborative participation from local stakeholders is of great importance to maintain the long-term goal of ecological restoration.

As the iconic species, giant panda's (Ailuropoda melanoleuca) natural habitat has improved significantly in China in recent years, and giant panda's extinction risk has been downgraded from "endangered" to "vulnerable" $[18,19]$. However, the species is still vulnerable, and human disturbance is still a major cause of habitat fragmentation of giant pandas. The Chinese government has launched the Giant Panda National Park to enhance giant panda habitat's connectivity and to establish a multi-level ecological protection system $[20,21]$. However, its effectiveness is still under evaluation.

Rural community and household participation are essential to maintain the wellfunctioning of the National Park System. Previously, the increasing human activity has disturbed giant panda habitats through various ways such as livestock grazing, road construction, and herb collection [22]. Human disturbances could hinder bamboo growth rate, cause fecal pollution as well as change giant panda behaviors $[23,24]$. The fragmentation of forest vegetation caused by human activities and natural disasters results in the complexity of landscapes in giant panda habitats, which further halted the migration and species exchange and seriously threatened the function and integrity of giant panda habitat [25]. Forest vegetation restoration, biodiversity conservation, and ecological corridor construction are considered effective ways to improve the status quo of giant panda habitats [26]. A win-win solution of ecological protection and community development is expected through the tight cooperation with rural households by the giant panda national park program. As the most important stakeholder, rural households are expected to bear part of ecological restoration costs and participate in constructing the habitat.

Previous research mainly focused on alleviating the contradiction between habitats and surrounding households $[27,28]$, ensuring benefits and development of the habitat $[29,30]$, and promoting rural socio-economic development [31,32]. Although households' willingness and preference for environmental protection has received research attention, only a particular aspect or performance of a specific environmental function has been focused on [33,34]. A comprehensive exploration of rural households' preferences and willingness-to-pay (WTP) for whole aspects of ecological functions is needed to deepen the understanding of rural household protection attitudes and behaviors, as they contribute a crucial significance to the sustainable development of natural habitats in the long run.

Hence, this study was designed to explore households' preferences for ecological restoration attributes and willingness to pay for ecological restoration using the discrete choice experiment (DCE). Specifically, this study aims to (1) analyze factors that affect households' preferences and willingness to pay for ecological restoration; (2) calculate households' marginal payment value of each ecological restoration attribute; (3) calculate the payment value of each choice option designed in DCE and select the best choice option that rural households preferred. This analysis could help to understand rural households attitudes towards ecological restoration in and around giant panda national habitats and is of great significance to ecological protection and development of habitats.

\section{Materials and Methods}

\subsection{Data}

Giant panda national park involves 12 cities and 29 counties (districts) in Sichuan, Shanxi, and Gansu provinces with a total area of $27,134 \mathrm{~km}^{2}$. The national park in Sichuan province is the largest part, covering an area of $20,100 \mathrm{~km}^{2}$ (with 1205 wild giant pandas), 
accounting for $74.08 \%$ of the total areas $(64.65 \%$ of the total wild giant pandas). In addition, giant panda habitats in Sichuan Province are also selected as one of the 25 global biodiversity hotspots by Conservation International. Based on this, we conducted a questionnaire survey around giant panda habitats in Sichuan province in 2019. The sampling method was a combination of stratified sampling and village-level random sampling. Specifically, 12 out of 46 giant panda nature reserves at the national, provincial, and municipal levels were selected based on stratified sampling. The selected giant panda nature reserves covered four cities (Chengdu, Mianyang, Deyang, and Ya'an) and 12 counties. Four villages in each nature reserve were selected, and in total 48 villages in and around giant panda habitats were investigated. Furthermore, 9-11 households were randomly selected in each village, constituting 500 households participating in our survey.

The valid sample size was 474 , with an effective response rate of $96.8 \%$. The data collection process encompassed a structured questionnaire in combination with a discrete choice experiment. The data collection team included six well-experienced Ph.D. students and 12 Master's Degree students. A clear explanation of the discrete choice experiment was guaranteed through the training and practices to ensure rural households understood their choices. On average, the completion of each survey would take 30-40 min on site. The main content of the questionnaire includes three parts: the demographic characteristics of household heads and their family, the environment protection attitude and cognition of household heads, and their response to the choice experiment. The study sites cover major areas where giant pandas' activities can be tracked as well as potential areas where giant pandas may occasionally visit.

\subsection{Method}

The choice experiment has been widely used in research on public needs and preferences of various natural resources such as cultivated land, wetlands, forests, and organisms to measure the marginal willingness to pay to reflect the ecological value of various attributes of natural resources [35-40]. Compared to other methods, the choice experiment provides a feasible way to quantify the non-market value of ecological products and exerts advantages in reducing measurement errors to obtain more concrete individual preferences. Primarily, the choice experiment provides interviewees the opportunity to weigh various evaluation indicators to make multi-indicator decisions. Hence, through the choice experiment, there is a chance to explore rural households' attitudes, preferences, even perceived values of each restoration function from their choices. In our choice experiment design, households' preferences heterogeneity is evaluated by asking individual respondents $(n)$ with different socio-economic characteristics $(S)$ to compare the utilities $\left(U_{i n}\right)$ of a given set (C) of alternative choices (i) [41,42]. Four steps are generally followed through the choice experiment design process: (1) definition of attributes and their levels; (2) experimental design; (3) questionnaire development; and (4) sampling strategy.

In our design, households need to choose between three ecological restoration alternative options. The attribute selection and its level settings are based on literature review and expert consultation in November 2018 in Forestry Bureaus of Sichuan Province. Four primary ecological restoration means were defined as attributes: forest vegetation restoration, biodiversity conservation, giant panda corridor construction, and one-time willingness to pay. In addition, household respondents were asked to answer several follow-up questions regarding their personal and family status and their protection attitude and cognition through open questions or the Likert Scale [43]. Detailed descriptions of attribute levels and descriptive statistics of other demographic and attitude variables are presented in Table 1 below. Male respondents dominated the sampled households, accounting for $66.6 \%$. In terms of age, more than $70 \%$ of respondents are over 40 years old, representing mainly the middle-aged and elderly group. Half of the respondents have a primary school education, and the overall education level is comparatively low. The demographic condition is basically in line with the rural population structure of Sichuan province. In addition, the 
average household income is between 20,000 and 50,000 RMB, and the average forest size is about 6-30 $\mathrm{mu}(1 \mathrm{mu}=0.067$ hectares $)$ in our sampled households.

Generally, two 3-level attributes and two 4-level attributes produce $144(=4 \times 3 \times 3 \times 4)$ possible alternatives (as the full factorial experimental design). To choose as many effective alternative combinations as possible, D-optimal main-effects fractional factorial design was conducted, and finally, 16 choice options were selected [44]. These choice options are randomly allocated into eight choice sets (i.e., option A and Option B in each choice set). In addition, the third option is always the status-quo option in each choice set. In our questionnaire design, households are randomly allocated to four choice sets to make their choices (A choice set example see Table 2). The design and choice set definition steps followed the guide of Aizaki et al. [45].

We estimated a mixed logit model based on random utility theory [46]. In the model, the utility for alternative $(i)$ for individual $(n)$ is assumed to be:

$$
U_{\text {in }}=V_{\text {in }}\left(C_{i}, S_{n}\right)+\varepsilon_{\text {in }}\left(C_{i}, S_{n}\right)
$$

where $V_{i n}$ is the deterministic component, or indirect utility function; $\varepsilon_{i n}$ is the random unobservable error term. $C_{i}$ refers to the chosen attribute (i) from ecological restoration choice sets $(C)$, such as forest vegetation restoration, biodiversity conservation, ecological corridor construction, and willingness to pay for participation. $S_{n}$ refers to individual respondents' $(n)$ socio-economic characteristics $(S)$, such as gender, age, education level, etc.

The linear function can be expressed as:

$$
U_{i n}=\alpha_{1}+\beta_{0} \text { Price }_{i n}+\sum_{k=1}^{K} \beta_{i k} C_{i n k}+\sum_{m=1}^{M} \gamma_{n m} S_{n m}+\varepsilon_{i n}
$$

where $C_{i n k}$ is the level of attribute $\mathrm{k}$ from alternative $\mathrm{i}$ and $\beta_{i k}$ is the corresponding utility coefficient. $S_{n m}$ is the $\mathrm{m}$ characteristics of respondent $n$ and $\gamma_{n m}$ is the corresponding utility coefficient.

The probability that an individual will choose alternative (i) over the alternative $(j)$ can be expressed as the probability that the utility for $(i)$ is larger than the utility for $(j)$ and is expressed as:

$$
P_{i n}=\frac{\exp \left(V_{i n}\right)}{\sum_{j=1}^{J} \exp \left(V_{j n}\right)}
$$

The households' willingness to pay for ecosystem restoration is the price premium that one is willing to pay for the required level of restoration attributes. For example, if a respondent is expected to care more about forest vegetation restoration than biodiversity conservation, then its WTP is a price premium that a respondent is willing to pay for improving forest vegetation rather than improving biodiversity. Based on the mixed logit regression, the WTP for improving the level of ecological restoration attributes is calculated as follows:

$$
W T P=-\frac{\beta_{r}}{\beta_{p}}
$$

where $\beta_{r}$ and $\beta_{p}$ represent the estimated parameters of specific environmental restoration attributes $r$ and price attributes $p$, respectively. WTP represents the marginal willingness to pay (marginal utility) of each attribute level and based on that the value change caused by the marginal change of each attribute level can be obtained [47]. 
Table 1. Variable definition and description.

\begin{tabular}{|c|c|c|c|c|c|c|c|c|}
\hline Variables & Abbreviation & \multicolumn{2}{|c|}{ Definition and Description } & Percentage $(\%)$ & Mean & Std.Dev. & Min & Max \\
\hline Explained variable & $\mathrm{Y}$ & \multicolumn{2}{|c|}{ Choice option selection result: selected $=1$, unselected $=0$} & & & & & \\
\hline \multirow{5}{*}{$\begin{array}{l}\text { Explanatory variable } \\
\text { (Attributes) }\end{array}$} & FV & \multicolumn{2}{|c|}{$\begin{array}{c}\text { Forest vegetation restoration: } \\
1=\text { Maintaining the current status } \\
2=\text { Ban in logging/deforestation } \\
3=\text { Forest restoration actions } \\
4=\text { Ban in logging/deforestation + Forest restoration actions }\end{array}$} & & & & & \\
\hline & $\mathrm{BD}$ & \multicolumn{2}{|c|}{$\begin{array}{l}\text { Biodiversity conservation: } \\
1=\text { Maintaining the current status } \\
2=\text { Preventing species loss } \\
3=\text { Improving biodiversity }\end{array}$} & & & & & \\
\hline & $\mathrm{CC}$ & \multicolumn{2}{|c|}{$\begin{array}{c}\text { Giant panda corridor construction: } \\
1=\text { Maintaining the current status } \\
2=\text { Preventing fragmentation of giant panda habitat } \\
3=\text { Building panda corridor and strengthening population exchanges }\end{array}$} & & & & & \\
\hline & WTP & \multicolumn{2}{|c|}{ One-time willingness to pay: $1=0 \mathrm{RMB}, 2=50 \mathrm{RMB}, 3=100 \mathrm{RMB}, 4=200 \mathrm{RMB}$} & & & & & \\
\hline & ASC & \multicolumn{2}{|c|}{ Substituting constant variables: choose option $\mathrm{C}=0$, choose option $\mathrm{A}, \mathrm{B}=1$} & & & & & \\
\hline & Gen & Gender & male $=1$ & 66.57 & 0.726 & 0.446 & 0 & 1 \\
\hline & \multirow{5}{*}{ Age } & \multirow{5}{*}{ Age } & $1=\leq 29$ years old & 6.26 & \multirow{5}{*}{3.479} & \multirow{5}{*}{1.019} & \multirow{5}{*}{1} & \multirow{5}{*}{5} \\
\hline & & & $2=30 \sim 39$ years old & 18.43 & & & & \\
\hline & & & $3=40 \sim 49$ years old & 37.43 & & & & \\
\hline & & & $4=50 \sim 59$ years old & 20.23 & & & & \\
\hline \multirow{5}{*}{$\begin{array}{l}\text { Explanatory variable } \\
\text { (Non-attributes) }\end{array}$} & & & $5=\geq 60$ years old & 17.65 & & & & \\
\hline & \multirow{4}{*}{ Edu } & \multirow{4}{*}{ Years of education: measured value } & $\leq 6$ years & 48.72 & \multirow{4}{*}{6.937} & \multirow{4}{*}{2.864} & \multirow{4}{*}{0} & \multirow{4}{*}{15} \\
\hline & & & 6 9 years & 37.13 & & & & \\
\hline & & & 9 12 years & 9.07 & & & & \\
\hline & & & $\geq 12$ years & 5.08 & & & & \\
\hline
\end{tabular}


Table 1. Cont

\begin{tabular}{|c|c|c|c|c|c|c|c|c|}
\hline \multirow[t]{14}{*}{ Variables } & Abbreviation & Defin & scription & Percentage (\%) & Mean & Std.Dev. & Min & Max \\
\hline & \multirow{7}{*}{ Inc } & \multirow{7}{*}{ Household annual income: } & $1=\leq 20,000 \mathrm{RMB}$ & 11.60 & \multirow{7}{*}{2.869} & \multirow{7}{*}{1.497} & \multirow{7}{*}{1} & \multirow{7}{*}{8} \\
\hline & & & $2=20,001 \sim 50,000$ RMB & 22.74 & & & & \\
\hline & & & $3=50,001 \sim 80,000 \mathrm{RMB}$ & 24.07 & & & & \\
\hline & & & $4=80,001 \sim 110,000 \mathrm{RMB}$ & 14.92 & & & & \\
\hline & & & $5=110,001 \sim 140,000$ RMB & 12.06 & & & & \\
\hline & & & $6=140,001 \sim 170,000$ RMB & 5.91 & & & & \\
\hline & & & $8=\geq 200,000 \mathrm{RMB}$ & 7.17 & & & & \\
\hline & \multirow{5}{*}{ Eoa } & \multirow{5}{*}{ Forest size } & $1=5 \mathrm{mu}$ and below & 18.32 & \multirow{5}{*}{2.380} & \multirow{5}{*}{1.381} & \multirow{5}{*}{1} & \multirow{5}{*}{5} \\
\hline & & & $2=6$ to $30 \mathrm{mu}$ & 20.45 & & & & \\
\hline & & & $3=31$ to $55 \mathrm{mu}$ & 31.76 & & & & \\
\hline & & & $4=56$ to $80 \mathrm{mu}$ & 19.21 & & & & \\
\hline & & & $5=$ over $80 \mathrm{mu}$ & 10.26 & & & & \\
\hline & Mri & Whether household operates or & tourism and related industries: $1=$ & & 0.278 & 0.448 & 0 & 1 \\
\hline \multirow{5}{*}{$\begin{array}{l}\text { Household protection } \\
\text { attitude and cognition }\end{array}$} & Erc & \multicolumn{2}{|c|}{$\begin{array}{c}\text { Compared with ecological protection, economic development: } 1=\text { less important, } 2 \\
\text { = same important, } 3=\text { more important }\end{array}$} & & 1.979 & 0.787 & 1 & 3 \\
\hline & Rid & \multicolumn{2}{|c|}{$\begin{array}{l}\text { Times of contact with the management personnel of nature reserve per year: } 1=\text { no } \\
\text { contact, } 2 \leq 10 \text { times, } 3=11-99 \text { times, } 4 \geq 100 \text { times }\end{array}$} & & 1.983 & 0.703 & 1 & 3 \\
\hline & Uig & \multicolumn{2}{|c|}{$\begin{array}{c}\text { Willingness to participate in environmental governance: } 1=\text { generally willing, } 2= \\
\text { relatively willing, } 3=\text { very willing }\end{array}$} & & 1.762 & 0.588 & 1 & 3 \\
\hline & Und & \multicolumn{2}{|c|}{$\begin{array}{l}\text { Knowing the relevant laws and regulations: } 1=\text { do not know well, } 2=\text { understand, } \\
\qquad 3=\text { understand very well }\end{array}$} & & 1.362 & 0.632 & 1 & 3 \\
\hline & Par & \multicolumn{2}{|c|}{$\begin{array}{c}\text { Having conflicts between household livelihood and nature reserve management: } 1 \\
\text { = disagree, } 2=\text { general agree, } 3=\text { strongly agree }\end{array}$} & & 1.454 & 0.622 & 1 & 3 \\
\hline \multirow{2}{*}{ Specific variables } & PID & \multicolumn{2}{|c|}{ Respondent's number: 474 (valid questionnaire) } & & & & & \\
\hline & CID & \multicolumn{2}{|c|}{ Selection choice set number: 1896} & & & & & \\
\hline
\end{tabular}


Table 2. Choice set example.

\begin{tabular}{|c|c|c|c|c|}
\hline & Attributes & Option A & Option B & Status Quo \\
\hline \multirow{5}{*}{$\begin{array}{l}\text { Choice } \\
\text { Set } 1\end{array}$} & $\begin{array}{l}\text { Forest vegetation } \\
\text { restoration }\end{array}$ & $\begin{array}{l}\text { Maintaining the } \\
\text { current status }\end{array}$ & Forest restoration actions & $\begin{array}{l}\text { Maintaining the } \\
\text { current status }\end{array}$ \\
\hline & Biodiversity conservation & Preventing species loss & $\begin{array}{l}\text { Maintaining the } \\
\text { current status }\end{array}$ & $\begin{array}{l}\text { Maintaining the } \\
\text { current status }\end{array}$ \\
\hline & $\begin{array}{l}\text { Giant panda } \\
\text { corridor construction }\end{array}$ & $\begin{array}{l}\text { Building panda corridor } \\
\text { and strengthening } \\
\text { population exchanges }\end{array}$ & $\begin{array}{l}\text { Preventing fragmentation } \\
\text { of giant panda habitat }\end{array}$ & $\begin{array}{l}\text { Maintaining the } \\
\text { current status }\end{array}$ \\
\hline & Willingness to pay & $100 \mathrm{RMB}$ & $50 \mathrm{RMB}$ & 0 RMB \\
\hline & $\begin{array}{l}\text { Your choice (please } \\
\text { choose one only) }\end{array}$ & Option $\mathbf{A} \square$ & Option B $\square$ & Status quo $\square$ \\
\hline
\end{tabular}

\section{Results}

The results from the mixed logit model are presented in Table 3 below. In Model 1, all attribute parameters designed in the experimental choice set are significant. Forest vegetation restoration, biodiversity protection, and giant panda corridor construction positively impact households' utility, showing an active attitude towards the improvement of ecological restoration functions. The one-time willingness to pay is significantly negative, indicating a decreasing utility of choice set with a higher payment. Hence, rural households generally tend to pay fewer costs to obtain better habitat ecological restoration functions in their choices.

Table 3. Estimation results from mixed logit regression.

\begin{tabular}{|c|c|c|c|c|c|c|}
\hline \multirow{2}{*}{$\begin{array}{l}\text { Independent } \\
\text { Variables }\end{array}$} & \multicolumn{3}{|c|}{ Model 1} & \multicolumn{3}{|c|}{ Model 2} \\
\hline & Coefficient & Std.Error & Z Value & Coefficient & Std.Error & Z Value \\
\hline \multicolumn{7}{|l|}{ Attributes } \\
\hline FV & $0.3005^{* * *}$ & 0.0671 & 4.48 & $0.3240^{* * *}$ & 0.0721 & 4.49 \\
\hline $\mathrm{BD}$ & $0.2435^{* * *}$ & 0.0547 & 4.45 & $0.2600^{* * *}$ & 0.0560 & 4.64 \\
\hline $\mathrm{CC}$ & $0.1604^{* * *}$ & 0.0506 & 3.17 & $0.2134^{* * *}$ & 0.0510 & 4.18 \\
\hline WP & $-0.1033^{* * *}$ & 0.0389 & -2.65 & $-0.0730 *$ & 0.0394 & -1.85 \\
\hline ASC & $-0.1142 * *$ & 0.0631 & -1.81 & $-0.9024^{* * *}$ & 0.2453 & -3.68 \\
\hline \multicolumn{7}{|c|}{ Household characteristics } \\
\hline Gen & & & & -0.4047 & 0.2478 & -1.63 \\
\hline Age & & & & $0.2276^{* *}$ & 0.1074 & 2.12 \\
\hline Edu & & & & $0.1378^{* * *}$ & 0.0443 & 3.11 \\
\hline Inc & & & & 0.1723 * & 0.1035 & 1.66 \\
\hline Eoa & & & & 0.0950 & 0.0836 & 1.14 \\
\hline \multicolumn{7}{|c|}{$\begin{array}{l}\text { Household protection } \\
\text { attitudes and cognition }\end{array}$} \\
\hline Mri & & & & 0.0561 & 0.2664 & 0.21 \\
\hline Erc & & & & $-0.3045^{* *}$ & 0.1340 & -2.27 \\
\hline Rid & & & & 0.0141 & 0.1816 & 0.08 \\
\hline Uig & & & & $0.5408^{* * *}$ & 0.1805 & 3.00 \\
\hline Und & & & & -0.2045 & 0.1984 & -1.03 \\
\hline Par & & & & $-0.3632 *$ & 0.1984 & -1.83 \\
\hline Log-likelihood & & -1986.8064 & & & -1907.921 & \\
\hline Wald chi2 & & 92.81 & & & 180.38 & \\
\hline Prob > chi2 & & 0.0000 & & & 0.0000 & \\
\hline
\end{tabular}

Note: ${ }^{* * *}, * * *$ indicate the significance level of $1 \%, 5 \%$, and $10 \%$, respectively.

In Model 2, household characteristics indicators, their environmental attitudes, and cognitions are included. The results show that household head's age, education level, and annual household income positively impact household utility. In addition, willingness to participate in environmental governance also has a positive impact on households' utility, 
whereas the cognition of the importance of economic development rather than ecological protection and a conflict between household livelihood and nature reserve management would negatively impact on household's utility.

Based on the estimation results from the mixed Logit model, this paper further calculated the marginal value of each attribute of ecological restoration relative to the baseline level (status-quo). The calculated marginal value is the willingness to pay for improving the attribute by households (see Table 4). From Model 1, the marginal value of forest vegetation restoration (2.91 RMB) is higher than the marginal value of biodiversity protection (2.36 RMB) and giant panda corridor construction (1.55 RMB). Although the calculation of the unit marginal value is higher in Model 2, there are no logical differences comparing to the results from Model 1.

Table 4. The marginal value of ecological restoration attributes.

\begin{tabular}{cccc}
\hline Attribute Variable & Expression & Model 1 (RMB) & Model 2 (RMB) \\
\hline Forest vegetation restoration (Z1) & MWTPZ1 $=-\beta 1 / \beta 4$ & 2.91 & 4.44 \\
Biodiversity conservation (Z2) & MWTPZ2 $=-\beta 2 / \beta 4$ & 2.36 & 3.56 \\
Giant panda corridor & MWTPZ3 $=-\beta 3 / \beta 4$ & 1.55 & 2.92 \\
construction (Z3) & & & \\
\hline
\end{tabular}

Furthermore, based on 16 identified choices options, this paper calculated the improvement of the attribute status of each choice option compared with the status-quo, as well as the relative value change of each choice option (see Table 5). Choice option 5 is the best choice option for households among all choice options. Households would prefer to restore forest vegetation and increase biodiversity but maintain the current status of corridor construction. In model 1, households would be willing to pay $21.81 \mathrm{RMB}$ for the best choice option (and would be willing to pay for $34.28 \mathrm{RMB}$ in model 2). Since the least willingness to pay is $0 \mathrm{RMB}$ in initial settings, the household's willingness to pay could reach 34.28 RMB for the best combination choice option of ecological restoration.

Table 5. Value accounting results of all choice options of ecological restoration.

\begin{tabular}{cccccc}
\hline & \multicolumn{2}{c}{ Attribute Status Descriptions } & \multicolumn{2}{c}{ Value Accounting (RMB) } \\
\cline { 2 - 6 } Option & $\begin{array}{c}\text { Forest Vegetation } \\
\text { Restoration }\end{array}$ & $\begin{array}{c}\text { Biodiversity } \\
\text { Conservation }\end{array}$ & $\begin{array}{c}\text { Giant Panda } \\
\text { Corridor } \\
\text { Construction }\end{array}$ & Model 1 & Model 2 \\
\hline 1 & 3 & 3 & 1 & 17.35 & 26.92 \\
2 & 1 & 3 & 1 & 11.53 & 18.05 \\
3 & 4 & 1 & 3 & 18.65 & 30.08 \\
4 & 2 & 2 & 3 & 15.19 & 24.77 \\
5 & 4 & 3 & 2 & 21.81 & 34.28 \\
6 & 2 & 2 & 1 & 12.09 & 18.92 \\
7 & 3 & 2 & 1 & 6.82 & 23.36 \\
8 & 1 & 1 & 2 & 15.55 & 10.92 \\
9 & 4 & 1 & 3 & 11.28 & 24.24 \\
10 & 2 & 1 & 2 & 15.74 & 18.28 \\
1 & 3 & 1 & 3 & 10.73 & 25.65 \\
13 & 1 & 2 & 1 & 1.01 & 17.41 \\
14 & 4 & 2 & 2 & 14.44 & 33.65 \\
16 & 2 & 3 & 1 & 14.19 & 22.48 \\
\end{tabular}




\section{Discussion and Conclusions}

Ecosystem restoration requires not only scale-up efforts to halt and reserve the degradation, but also to provide sustainable goods and services that people need [48]. Hence, the active participation of locals is crucially important to maintaining the long-term restoration goals. This paper explores the households' preference for ecological restoration attributes and willingness to pay for ecological restoration using the discrete choice experiment. Three ecological restoration attributes and one monetary attribute were considered in the study. The analysis indicates that all ecological restoration attributes have a significant positive impact on rural household utility, whereas the payment has a negative impact, indicating that rural households are inclined to pay less to gain more restoration benefits. In addition, the household head's age, education level, household income, as well as households' positive attitudes and behaviors toward environmental protection have a positive impact on households' utility in improving ecological restoration functions.

Regarding the attribute value calculations, rankings of households' marginal willingness to pay are forest vegetation restoration, biodiversity protection, and giant panda corridor construction. The result shows the high consensus on the importance of forest vegetation restoration among rural households. It could be explained by the fact that about $60 \%$ of households have a forest size of more than 2 hectares and the forest vegetation restorations are directly related to their daily interests. In addition, the sample areas of our research have long traditions in economic/medical crop plantations, so restoration and protection of forest vegetation are beneficial to the growth of medicinal crops. Hence, households have the highest willingness to pay for forest vegetation restoration in the analysis.

Although households are generally willing to pay for ecological restoration, the payment amount is not very high, especially to the attribute of giant panda corridor construction (only $2.92 \mathrm{RMB}$ ). It could be explained by the fact of unrelatedness of the attribute to rural households' daily life as well as their limited education level and lack of cognition on giant panda behaviors. Thus, it could be a future research direction to in-depth explore the rural household heterogeneity in preferences and WTP for ecological restoration. In addition, although the choice experiment expends ways to quantify and evaluate the non-market value of natural resources, rural households still make choices under hypothetical scenarios without actual payments. Therefore, there is a possibility of overestimating or underestimating the WTP of ecological restoration. Hence, introducing more effective error control methods into questionnaire design and field surveys would also be a direction in future research.

From the policy implication perspective, this paper shows an understanding of rural households' attitudes towards ecological restoration, which is a fundamental requirement to effectively adopt or implement any long-term ecological conservation plan. Since giant panda habitat covers large areas and couples with complex natural conditions and populations, the government needs to fully consider the needs of rural households who live in or around giant panda habitat to improve the applicability of relevant policies. The lack of recognition of the giant panda corridor indicates the need to strengthen the promotion of ecological restoration and further enhance rural households' understanding of the service attribute of giant panda corridor construction to actively promote the restoration participation of rural households. Moreover, rural households' WTP for different ecological restoration attributes reflect the underlying value and utility differences that direct their practical conservation behaviors. Hence, this paper highlights the need to explore the distinction between notional ecological policy and practical local participation in planning and implementing conservation plans. A better understanding of rural attitudes will foster the support of giant panda habitat protection and trigger rural household behavioral changes towards active, collaborative, and sustainable in the future. However, we have to admit that rural households' ecological requirement is beyond the basic livelihood needs, so increasing household income levels, improving social securities, and creating 
local livelihood possibilities are still extremely important to consolidate the foundation of ecological development in giant panda habitats.

Author Contributions: Conceptualization, Y.Z. and W.D.; methodology, H.W. and Y.Z.; formal analysis, H.W., Y.Z. and W.D.; writing—original draft preparation, Y.Z. and H.W.; writing—review and editing, Y.Z. and W.D. All authors have read and agreed to the published version of the manuscript.

Funding: This research was funded by [National Natural Science Foundation of China-Major International (Regional) Joint Research Project] grant number [71761147003] and [National Natural Science Foundation of China] grant number [71803050].

Institutional Review Board Statement: Not applicable.

Informed Consent Statement: Not applicable.

Data Availability Statement: Data available on request due to restrictions.

Conflicts of Interest: The authors declare no conflict of interest.

\section{References}

1. SER. International Primer on Ecological Restoration; Society for Ecological Restoration: Washington, DC, USA, 2004.

2. Romanelli, J.P.; Fujimoto, J.T.; Ferreira, M.D.; Milanez, D.H. Assessing ecological restoration as a research topic using bibliometric indicators. Ecol. Eng. 2018, 120, 311-320. [CrossRef]

3. Zhou, J.M. Research on the Evaluation System of Giant Panda Habitat Quality. Ph.D. Thesis, Beijing Forestry University, Beijing, China, 2008. (In Chinese).

4. Sterling, E.J.; Betley, E.; Sigouin, A.; Gomez, A.; Toomey, A.; Cullman, G.; Porzecanski, A.L. Assessing the evidence for stakeholder engagement in biodiversity conservation. Biol. Conserv. 2017, 209, 159-171. [CrossRef]

5. Hansen, M.H.; Li, H.; Svarverud, R. Ecological civilization: Interpreting the Chinese past, projecting the global future. Glob. Environ. Chang. 2018, 53, 195-203. [CrossRef]

6. Peng, B.; Li, Y.; Elahi, E.; Wei, G. Dynamic evolution of ecological carrying capacity based on the ecological footprint theory: A case study of Jiangsu province. Ecol. Indic. 2019, 99, 19-26. [CrossRef]

7. Pan, H.; Zhuang, M.; Geng, Y.; Wu, F.; Dong, H. Energy-based ecological footprint analysis for a mega-city: The dynamic changes of Shanghai. J. Clean. Prod. 2019, 210, 552-562. [CrossRef]

8. Zhang, J.Y.; Su, W.C.; Wang, L.C. Review on Impacts of Chinese Ecological Restoration Construction on Household Livelihoods. Ecol. Econ. 2018, 34, 180-185. (In Chinese)

9. Budiharta, S.; Meijaard, E.; Wells, J.A.; Abram, N.K.; Wilson, K.A. Enhancing feasibility: Incorporating a socio-ecological systems framework into restoration planning. Environ. Sci. Policy 2016, 64, 83-92. [CrossRef]

10. Zhang, J.; Mengting, L.; Hui, Y.; Xiyun, C.; Chong, F. Critical thresholds in ecological restoration to achieve optimal ecosystem services: An analysis based on forest ecosystem restoration projects in China. Land Use Policy 2018, 76, 675-678. [CrossRef]

11. Tan, H.L.; Wen, L.Y.; Xu, Y.; Qin, Q. Strategies to Protect Giant Pandas in Sichuan's Habitat Surrounding Communities from the Perspective of Farmers' Behavior. Resour. Dev. Mark. 2019, 35, 673-677, 740. (In Chinese)

12. Wang, C.C.; Yang, Y.S. Review of Research on Mountainous Ecological Restoration Based on Farmer Household Livelihood Evolution. J. Nat. Resour. 2011, 26, 344-352. (In Chinese)

13. Bixler, R.P.; Dell'Angelo, J.; Mfune, O.; Roba, H. The political ecology of participatory conservation: Institutions and discourse. J. Political Ecol. 2015, 22, 164-182. [CrossRef]

14. Liu, J.; Miao, H.; Zheng, H.; Ouyang, Z.Y.; Wang, X.K.; Li, X.G.; Jiang, B. Discussion about the relationship pattern between Wolong Nature Reserve and local community. Acta Ecol. Sin. 2009, 29, 259-271. (In Chinese)

15. Qiao, Y.; Tan, S.M.; He, Y.J. Impact of National Nature Reserve on the Livelihood Ability of Farmers in the Area. Issues For. Econ. 2020, 40, 337-344. (In Chinese)

16. Wang, Y.; Zhang, P.Y. Habitat assessment of giant panda in Qingmuchuan Nature Reserve, Shaanxi Province of Northwest China. Chin. J. Appl. Ecol. 2020, 23, 337-344. (In Chinese)

17. Cao, S.; Zheng, X.; Chen, L.; Ma, H.; Xia, J. Using the green purchase method to help farmers escape the poverty trap in semiarid China. Agron. Sustain. Dev. 2017, 37, 7. [CrossRef]

18. Swaisgood, R.; Wang, D.; Wei, F. Ailuropoda melanoleuca (errata version published in 2017). The IUCN Red List of Threatened Species; e.T712A121745669; 2016. Available online: http:/ / www.iucnredlist.org/details/712/0 (accessed on 11 October 2021).

19. Xiaoping, T.; Jiansheng, J.A.; Zhichen, W.; Dehui, Z.; Baocheng, Y.; Jianbing, Y.; Yang, L. Scheme design and main result analysis of the fouth national survey on giant pandas. For. Resour. Manag. 2015, 1, 11.

20. Xue, C.; Shao, C.; Gao, J. Ecological compensation strategy for SDG-based basin-type national parks: A case study of the Baoxing Giant Panda National Park. Int. J. Environ. Res. Public Health 2020, 17, 3908. [CrossRef]

21. State Council of PRC. 2018. Available online: http://www.gov.cn/xinwen/2018-10/29/content_5335501.htm (accessed on 11 October 2021). 
22. Sichuan Forestry Department. The Pandas of Sichuan: The 4th Survey Report on Giant Panda in Sichuan Province; Sichuan Publishing House of science Technology: Sichuan, China, 2015.

23. Li, B.V.; Pimm, S.L.; Li, S.; Zhao, L.; Luo, C. Free-ranging livestock threaten the long-term survival of giant pandas. Biol. Conserv. 2017, 216, 18-25. [CrossRef]

24. Kang, D.; Zhao, Z.; Chen, X.; Wang, X.; Li, J. Characteristics and impacts of solid waste on giant panda habitat in Wang lang Nature Reserve. Sci. Total Environ. 2020, 724, 138210. [CrossRef]

25. Connor, T.; Qiao, M.; Scribner, K.; Zhang, J.; Hull, V.; Bai, W.; Liu, J. Complex effects of habitat amount and fragmentation on functional connectivity and inbreeding in a giant panda population. Conserv. Biol. 2021. [CrossRef]

26. Mace, G.M. Whose conservation? Science 2014, 345, 1558-1560. [CrossRef]

27. Song, S.; Liu, Q.B.; Wen, Y.L. An analysis of determinants of natural resources dependence in the communities surrounding Qinling Giant Panda Protection Area. J. Zhejiang AEF Univ. 2016, 33, 130-136. (In Chinese)

28. Duan, W.; Ren, Y.M.; Feng, J.; Wen, Y.L. Research on Farmer Households' Dependence on Natural Resources Based on Livelihood Capital-A Case Study of Protected Areas in Hubei Province. Issues Agric. Econ. 2015, 36, 74-82, 112. (In Chinese)

29. Qin, Q.; Liu, J.R.; Ma, B.; Tan, H.L.; Xu, Y.; Wen, Y.L. Analysis on the Utilization Mode and Influencing Factors of Natural Resources in Sichuan Giant Panda Reserve and Its Surrounding Communities. Issues For. Econ. 2020, 40, 345-352. (In Chinese)

30. Vedeld, P.; Angelsen, A.; Bojö, J.; Sjaastad, E.; Berg, G.K. Forest environmental incomes and the rural poor. For. Policy Econ. 2007, 9, 869-879. [CrossRef]

31. Wang, C.H. What do Chinese nature reserves give to surrounding communities?-Based on the survey data of farmers in Shaanxi, Sichuan and Gansu from 1998 to 2014. Manag. World 2017, 3, 63-75. (In Chinese)

32. Wei, H.L.; Xu, Z.F. Improvement Countermeasures of Forest Resources Community Co-management from the Perspective of Economics. Rural Economy 2012, 4, 42-46. (In Chinese)

33. Zhang, H.N.; Ge, Y.X.; Jie, Y.M.; Zheng, Y.C. A study on the influence of ecological cognition on river basin residents' willingness to participate in ecological compensation. China Popul. Resour. Environ. 2019, 29, 109-116.

34. Odonkor, S.T.; Adom, P.K. Environment and health nexus in Ghana: A study on perceived relationship and willingness-toparticipate (WTP) in environmental policy design. Urban Clim. 2020, 34, 100689. [CrossRef]

35. Diafas, I.; Barkmann, J.; Mburu, J. Measurement of bequest value using a non-monetary payment in a choice experiment-The case of improving forest ecosystem services for the benefit of local communities in rural Kenya. Ecol. Econ. 2017, 140, 157-165. [CrossRef]

36. Shi, Y.; Li, C.; Zhao, M. Herders' aversion to wildlife population increases in grassland ecosystem conservation: Evidence from a choice experiment study. Glob. Ecol. Conserv. 2021, 30, e01777. [CrossRef]

37. Dushani, S.N.; Aanesen, M.; Vondolia, G.K. Balancing conservation goals and ecotourism development in coastal wetland management in Sri Lanka: A choice experiment. Ocean Coast. Manag. 2021, 210, 105659. [CrossRef]

38. Maldonado, J.H.; Moreno-Sanchez, R.; Henao-Henao, J.P.; Bruner, A. Does exclusion matter in conservation agreements? A case of mangrove users in the Ecuadorian coast using participatory choice experiments. World Dev. 2019, 123, 104619. [CrossRef]

39. Bocci, C.; Sohngen, B.; Lupi, F.; Milian, B. Timber or carbon? Evaluating forest conservation strategies through a discrete choice experiment. Ecol. Econ. 2020, 171, 106601. [CrossRef]

40. Subroy, V.; Rogers, A.A.; Kragt, M.E. To bait or not to bait: A discrete choice experiment on public preferences for native wildlife and conservation management in Western Australia. Ecol. Econ. 2018, 147, 114-122. [CrossRef]

41. Hanley, N.; MacMillan, D. Contingent valuation versus choice experiments: Estimating the benefits of environmentally sensitive areas in Scotland. J. Agric. Econ. 2000, 51, 129-132. [CrossRef]

42. Train, K. A Comparison of Hierarchical Bayes and Maximum Simulated Likelihood for Mixed Logit; University of California: Berkeley, CA, USA, 2001; pp. 1-13.

43. Zawojska, E.; Czajkowski, M. Re-examining empirical evidence on stated preferences: Importance of incentive compatibility. J. Environ. Econ. Policy 2017, 6, 374-403. [CrossRef]

44. Louviere, J.J.; Hensher, D.A.; Swait, J.D. Stated Choice Methods: Analysis and Applications; Cambridge University Press: Cambridge, $\mathrm{UK}, 2000$.

45. Aizaki, H.; Nakatani, T.; Sato, K. Stated Preference Methods Using R; CRC Press: Boca Raton, FL, USA, 2014.

46. McFadden, D. Conditional Logit Analysis of Qualitative Choice Behavior. In Frontiers in Econometrics; Zarembka, P., Ed.; Academic Press: New York, NY, USA, 1973; pp. 105-142.

47. Grafeld, S.; Oleson, K.; Barnes, M.; Peng, M.; Chan, C.; Weijerman, M. Divers' willingness to pay for improved coral reef conditions in Guam: An untapped source of funding for management and conservation? Ecol. Econ. 2016, 128, 202-213. [CrossRef]

48. Fischer, J.; Gardner, T.A.; Bennett, E.M.; Balvanera, P.; Biggs, R.; Carpenter, S.; Tenhunen, J. Advancing sustainability through mainstreaming a social-ecological systems perspective. Curr. Opin. Environ. Sustain. 2015, 14, 144-149. [CrossRef] 